\title{
Sweden sets ethical standards for use of genetic 'biobanks'
}

[MUNICH] The Swedish Medical Research Council (MRC) last month published Europe's fullest set of ethical guidelines on the use and control of 'biobanks' - tissue and health-science information banks that can be used for genetic research.

The guidelines were developed by the MRC's ethics committee, and their publication follows the founding at the beginning of the year of a private gene-broking company called UmanGenomics, whose modus operand $i$ was developed in parallel with the ethics committee's considerations.

UmanGenomics has exclusive rights to generate and sell genetic information from blood samples stored in a 15-year-old medical bank based on samples from 60 per cent of the geographically isolated population of Västerbotten, a county in northern Sweden.

The guidelines, which define biobanks as any banks storing biological samples or information that may be linked to an individual, stress the importance of protecting individual data. Thus, they advise, codes linking data held in a biobank to an individual should be kept within a public institution such as a university or medical authority. These codes should be broken only in exceptional circumstances with the approval of an independent ethics committee.

The ethics committee should also control all access to stored material, and no monopoly on access should be granted. Research projects that might exhaust any part of the stores should not normally be approved.

Informed consent should be sought from donors for every new use of their biological samples. The ethics committee should decide whether or not a research proposal involves a new use, or a use that does not diverge significantly from that for which informed consent has already been received. The quality of the material stored in biobanks, and the rules for selecting material to be stored, should be strictly controlled.

UmanGenomics, based in Västerbotten's county town Umeå (which provided the pun in the company's name), has been accepted by the community because it conforms with these guidelines, says Gisela Dahlquist, professor of paediatrics at the University of Umeå, who chairs the MRC's ethics committee.

The situation is different from that in Iceland, where a population-based biobank is to be generated and placed under the exclusive control of the US-based gene-broking company deCODE (see Nature 396, 395; 1998). The initiative has created great concern. According to a recent opinion poll, 25 per cent of Iceland's 250,000 population fear that

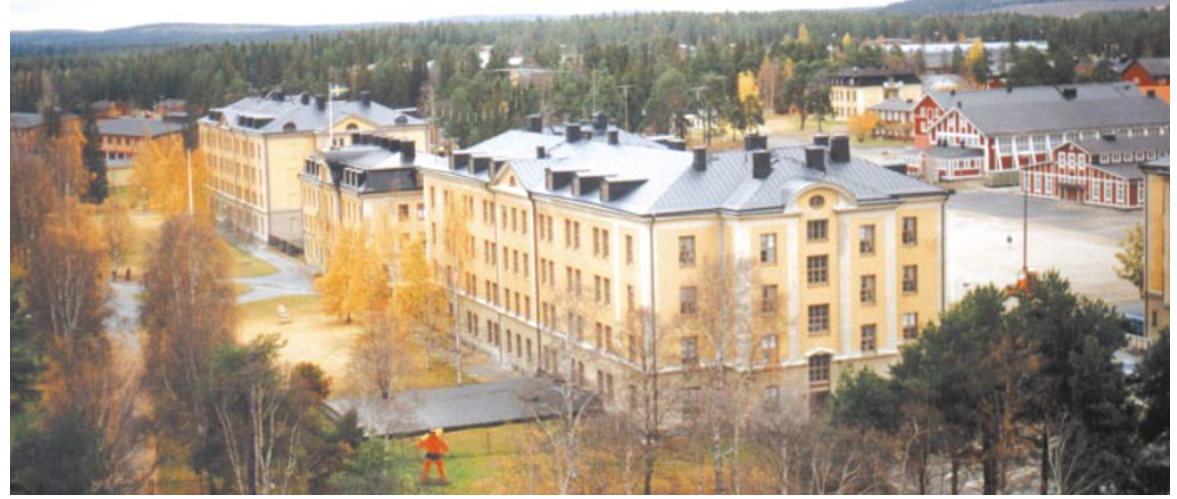

Advance guard: pioneering gene-broking company UmanGenomics - 51 per cent owned by local public bodies — will move next year into headquarters in Umeå recently vacated by the army.

deCODE could 'misuse' their genetic information. Moreover, basic researchers complain that they will have to buy information from deCODE at commercial rates.

It was the University of Umeå's new technology transfer unit, called Technology Bridge Foundation, which recognized the unique potential of Umeå's blood bank, now renamed the Medical Bank.

The Medical Bank was set up in 1985 as part of a general health screen after epidemiologists found that the local population had an unusually high mortality from cardiovascular disease. Västerbotten's 260,000 inhabitants were asked by their family doctors to give blood samples every ten years for research into the causes and treatment of the disease. A study in the early 1990s confirmed that there was no bias towards any socioeconomic group in those participating. Such an established and population-based bank, which companies like deCODE are trying to build from scratch, is believed to be unique.

Sune Rosell, former research director at Astra Pharmaceuticals and now temporary chairman of UmanGenomics, says the company worked with the Medical Bank, university researchers and local politicians to create a "unique formula" for handling ethical issues at different levels.

"There is control at the individual level through informed consent, at the social level through the regional ethics committee which screens all research proposals, and at the population level, since local politicians sit as non-voting members on the boards of both the company and the Medical Bank," he says.

Most important, says Rosell, is the fact that the local university and health authority own a 51 per cent stake in the company, and so have ultimate control over the genetic information that UmanGenomics will make available to pharmaceutical companies.
It is not just sensitivity to ethical issues that underlies the positive local response to the company, he adds. UmanGenomics has promised to bring high-tech jobs to the area by ensuring that research contracts are carried out locally. In addition, university researchers have free access to the Medical Bank, independent of UmanGenomics, which has exclusive commercial rights.

Many pharmaceutical companies have already shown great interest in collaborating with UmanGenomics, says Rosell. Contracts should be signed in the coming months.

In the meantime, four research projects funded by the Technology Bridge Foundation have begun at the university on diseases that have become concentrated in Västerbotten's isolated population. One involves a family that has a high incidence of cardiac infarcts at around 30 years of age, despite normal blood lipid levels. Another involves a family with decreased sensitivity to pain.

Västerbotten's regional ethics committee is responsible for deciding how to handle informed consent for the use of longarchived blood samples for genetic research. This will be arranged on a project-by-project basis, says Dahlquist.

"Informed consent was originally given by donors for cardiovascular research," she says, "so an ethics committee might, for example, require new individual informed consent for a study on schizophrenia. On the other hand - assuming an important, highquality project addressing a prevalent disease with presumed minimum harm to participants - it might decide a series of newspaper advertisements offering the opportunity to opt out might be appropriate."

The committee will also decide whether informed consent should be secured from relatives whose lives might be affected by the results of a genetic study.

Alison Abbott 